\title{
TCAP: Negative results in avoidance and water maze learning and retention'
}

\author{
F. ROBERT BRUSH, UNIVERSITY OF OREGON MEDICAL SCHOOL \\ JOHN W. DAVENPORT AND V. J. POLIDORA, UNIVERSITY OF WISCONSIN
}

The effects of TCAP, a compound reported to stimulate RNA synthesis, were studied in avoidance learning and water maze learning in rats. Contrary to a published study on avoidance learning and some unpublished data on water maze learning, neither situation revealed facilitation of ac quisition or retention by TCAP.

The compound 1, 1, 3-tricyano, 2-amino, 1-propene (TCAP) $^{2}$ has been reported by Egyhazi and Hyden (1961) to produce an increase in the RNA and protein content of Dieters' nerve cells in the rabbit while reducing their content in associated glial cells and markedly altering the base composition of the RNA in the two cell types. The potential significance of this compound for molecular theories of learning and memory has led a number of investigators, in work thus far largely unpublished, to study its effects in various learning situations. The only detailed published report on behavioral effects of TCAP known to the authors is one by Chamberlain, Rothschild, \& Gerard (1963) showing, among other findings, that retention of avoidance learning in rats is facilitated by a single intraperitoneal (i.p.) injection of TCAP on the first day of avoidance training. Among the unpublished studies is one by Essman (personal communication) showing facilitation of water maze performance in mice by chronic TCAP injections. In this report we present our results with TCAP in these two learning situations, both of which are basic training paradigms for longterm research programs.

\section{METHOD}

Experiments 1-3 were avoidance learning studies conducted in 4 identically-constructed shuttle boxes similar to those described by Brush (1962). Experiments 4-6 were water maze studies performed in the 6-unit T-maze described by Polidora, Cunningham, \& Waisman (in press). Ss were male albino and hooded rats approximately 100 days of age.

Avoidance studies

In all three avoidance learning experiments the basic procedural sequence was pretest, injection, and first avoidance training session on Day 1, followed by a second avoidance session, without injection, on Day 2. In Experiment 3 a third avoidance session was given on Day 3 without injection.

Conditions common to these three studies were (a) compound CS (light plus white noise); (b) constant intertrial interval of 2 min.; (c) 5-sec. CS-US interval; (d) overlap and simultaneous termination of CS and US on escape trials; (e) 10-trial pretest immediately preceding the Day 1 injections, each pretest trial having a 45-sec. maximum duration; and (f) TCAP dose of $15 \mathrm{mg} / \mathrm{kg}$ (concentration $5 \mathrm{mg} / \mathrm{ml}$ ) or an equivalent volume of vechicle placebo (benzyl alcohol, carbowax, and sodium hydoxide to adjust $\mathrm{pH}$ ) injected i.p. $45 \mathrm{~min}$. before avoidance training on the first experimental day only.

In Experiment 1, 16 hooded rats were given the pretest, injections ( $8 \mathrm{drug}, 8$ placebo), and 20 avoidance trials on Day 1 , followed by 20 more training trials on Day 2. Shock intensity was .25 ma. Since the overall level of avoidance responding in Experiment 1 waslow, the procedure was repeated in Experiment 2 with 24 additional hooded rats with the shock intensity increased to $.3 \mathrm{ma}$. Thirty-nine naive hooded rats (13 given TCAP, 13 placebo, and 13 uninjected), were used in Experiment 3 , and conditions were the same as in Experiment 2 except that three training sessions were administered, each consisting of 30 trials.

Water maze studies

In all three water maze studies, a 6-day procedure identical to that described by Polidora et al (in press) was used. Briefly, this consisted of straight alley training ( 1 day), 6-unit maze learning (3 days), and reversal ( 2 days, Ss run through the reverse maze route). In addition to the 6-day test, $\mathrm{Ss}$ in Experiments 4 and 5 were retested for retention 9 and 40 days later.

In Experiment 4, 12 hooded rats receiving $15 \mathrm{mg} / \mathrm{kg}$ TCAP and 11 saline control Ss were given 9 daily i.p. injections; 6 of these were given on the test days, $1 \mathrm{hr}$. before testing, and the remainder were given on the 3 days prior to testing. In Experiment 5,10 hooded rats receiving $15 \mathrm{mg} / \mathrm{kg} \mathrm{TCAP}$ and 10 saline controls were given 4 daily i.p. injections, 3 on the days preceding testing and 1 on the first test day only, again $1 \mathrm{hr}$. before testing. The Ss in Experiment 6 (13 albino rats on TCAP diet and 4 on control diet) were fed TCAP mixed in dry mash $(0.5 \mathrm{gm} / \mathrm{kg} /$ day $)$ or dry mash alone from weaning at 20 days of age through the last day of water maze testing, which was completed at approximately 100 days of age.

\section{Avoidance studies \\ RESULTS}

The results of the three avoidance experiments $(1,2$, and 3) are presented in Fig. 1 in terms of mean percentage of avoidance responses. Inspection of the data from all three studies revealed no significant group differences in number of avoidance responses, latency of responding, or number of intertrial responses. The apparent differences on Day 2 of Experiment 1 (upper portion of the figure) and on both test days of Experiment 2 (middle portion) were largely the result of extreme 


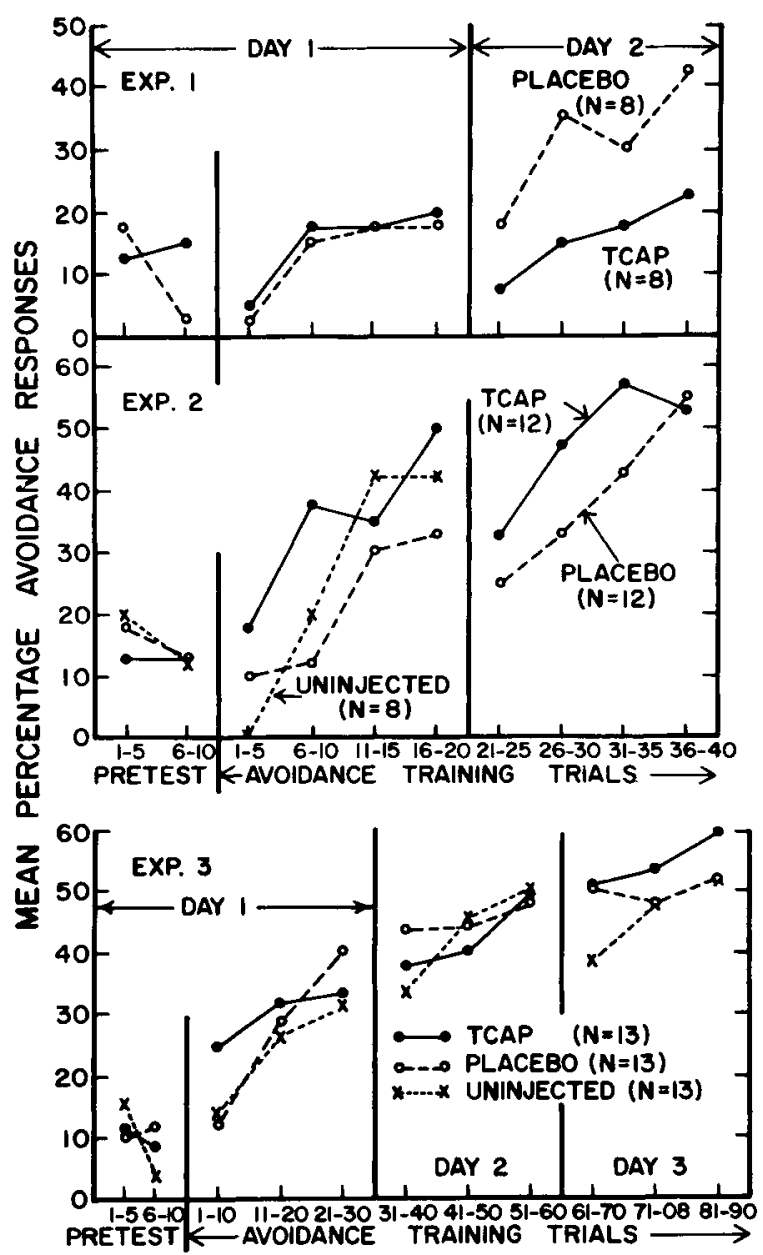

Fig. 1. Pretest and avoidance learning data from Exps. 1-3.

scores contributed by a single $S$ in each of these experiments. Considering the larger Ns and the stability of the data, we regard the negative results of Experiment 3 (lower portion, Fig. 1) to be the most reliable. Water maze studies

In Experiments 4, 5, and 6 no significant differences in errors or swimming speeds were found between TCAP-treated rats and controls in acquisition, reversal, or retention. The small but nonsignificant differences obtained were generally in the direction of superior performance by control Ss.

\section{DISCUSSION}

The avoidance learning findings contradict the results of Chamberlain et al (1963), who also used a TCAP dose level of $15 \mathrm{mg} / \mathrm{kg}$ i.p. $45 \mathrm{~min}$. before Day 1 trials and a highly similar training schedule consisting of three 25-trial sessions with a 2-min. intertrial interval. Other experimental conditions differed, however. The present studies were conducted in shuttle boxes whereas Chamberlain et al used a cylindrical bar-pressing apparatus. In addition, the training was preceded by a nonshock pretest in the present studies, whereas in their research it was preceded by $2510-\mathrm{sec}$. shocks randomly administered in a plain cylinder. Other differences were that Chamberlain et al used a buzzer CS, 10-sec. CS-US interval, saline control injection, and albino rats. It is conceivable, though not readily understandable, that some combination of these differences could account for the discrepancy in results. In any event, while our data do notdisprove the original finding of facilitation of avoidance learning by TCAP, they do indicate that, at best, it has remarkably limited generality.

The discrepancy between the present water maze results and the unpublished findings by Essman may be more understandable than in the case of the avoidance studies, in view of Essman's use of a higher dosage of TCAP (20 instead of $15 \mathrm{mg} / \mathrm{kg}$ ) and longer periods (30-120 days) of drug administration prior to testing. Other unpublished evidence is accumulating at the Wisconsin Primate Center and elsewhere which indicates that rats' and monkeys' performance in various learning tasks may be facilitated by chronic, but not by acute, administration of TCAP.

\section{References}

Brush, F. R. The effects of intertrial interval on avoidance learning in the rat. J. comp. physiol. Psychol., 1962, 55, 888-892.

Chamberlain, T. J., Rothschild, G. H., \& Gerard, R. W. Drugs affecting RNA and learning. Proc. Nat. Acad. Sci., 1963, 49, 918-924.

Egyhazi, E., \& Hyden, H. Experimentally induced changes in the base composition of the ribonucleic acids of isolated nerve cells and their oligodendroglial cells. $J$. biophys. biochem. Cytol., 1961, 10, 403-410.

Polidora, V. J., Cunniıgham, R. F., \& Waisman, H. A. Dosage parameters of a behavioral deficit associated with phenylketonuria in rats. J. comp. physiol. Psychol, in press.

\section{Notes}

1. Supported by National Institutes of Health grants FR-00167 and MH-03337, and funds from the Central Wisconsin Colony and Training School. We thank J. P. Dyrud and D. A. Snyder for assistance in gathering data.

2. This compound, 1, 1, 3-tricyano, 2-amino, 1-propene, a dimer of malononitrile, is also known by its Upjohn Co. designation, U-9189, and by abbreviations such as "tricyamp," "tri-a-p," and TCAP. 